AperTO - Archivio Istituzionale Open Access dell'Università di Torino

\title{
Endothelial Nitric Oxide Synthase intron 4 VNTR Gene polymorphisms in European and African populations
}

\section{This is a pre print version of the following article:}

Original Citation:

Availability:

This version is available http://hdl.handle.net/2318/130817

since 2016-01-04T09:52:07Z

Published version:

DOI:10.1007/s11033-012-1492-4

Terms of use:

Open Access

Anyone can freely access the full text of works made available as "Open Access". Works made available under a Creative Commons license can be used according to the terms and conditions of said license. Use of all other works requires consent of the right holder (author or publisher) if not exempted from copyright protection by the applicable law. 


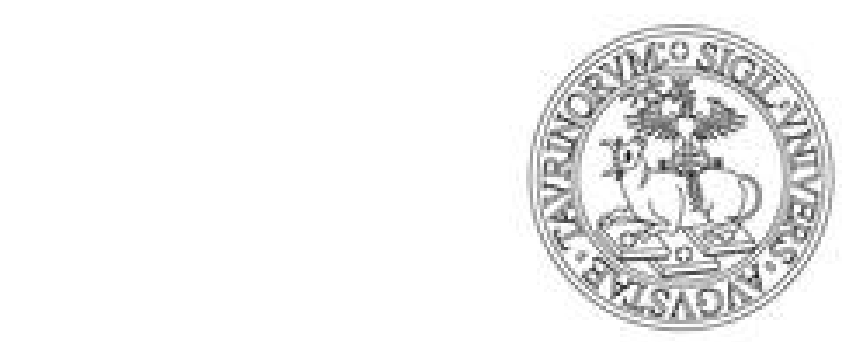

\section{UNIVERSITÀ DEGLI STUDI DI TORINO}

This is an author version of the contribution published on:

A. Santovito, P. Cervella, M. Delpero

Endothelial Nitric Oxide Synthase intron 4 VNTR Gene polymorphisms in European and African populations

MOLECULAR BIOLOGY REPORTS (2012) 39

DOI: $10.1007 / \mathrm{s} 11033-012-1492-4$

The definitive version is available at:

http://www.springerlink.com/index/pdf/10.1007/s11033-012-1492-4 
Endothelial Nitric Oxide Synthase intron 4 VNTR Gene polymorphisms in European and African populations

Alfredo SANTOVITO ${ }^{\mathrm{a}, \mathrm{b}}$, Piero CERVELLA ${ }^{\mathrm{a}}$, and Massimiliano DELPERO ${ }^{\mathrm{a}}$

a Department of Animal and Human Biology, University of Turin, Via Accademia Albertina n. 13, 10123 Torino (Italy)

*Corresponding Author:

Alfredo SANTOVITO

Dipartimento di Biologia Animale e dell’Uomo

Via Accademia Albertina n. 13

10123 - Torino (Italy)

Tel.: +39-0116704554

Fax: +39-0116704508

\begin{abstract}
Nitric oxide is an endogenous molecule that play an important role in the regulation of the systemic, cardiac and pulmonary circulations. We investigated the frequency of intron 4 VNTR ecNOS gene polymorphism in Ivorian and Italian populations. The frequencies of the $b b, a b$ and aa genotypes were $0.422,0.476$, and 0.102 , respectively, for the Ivorian sample, and $0.683,0.300$, and 0.017 , respectively, for the Italian sample. The frequencies of $4 \mathrm{~b}$ and $4 \mathrm{a}$ alleles were 0.660 and 0.340 , respectively, for the Ivorian group, and 0.833 and 0.167 , respectively, for the studied Italian population. The genotype frequencies were in Hardy-Weinberg equilibrium in both populations. No differences were found in ecNOS genotype and allele frequencies between sexes. The Ivorian population showed a significantly higher frequency of the 4a allele with respect to North African populations (Tunisia, Algeria and Morocco) and to the African-Brazilian sample. Viceversa, the Italian population did not show any significant differentiation with respect to other European
\end{abstract}


populations, with exception of the Holland and Turkey samples, confirming the high genetic homogeneity of Italy and Europe in the distribution of this polymorphism. In the Ivorian sample the 4a allele was prevalently found in a heterozygous status. A possible explanation could be that the heterozygote individuals produce a sufficient level of NO metabolites, although in lower amount with respect to the bb genotypes. As a consequence, the $4 \mathrm{a}$ allele is maintained prevalently in a heterozygous status and does not provoke an effective selective disadvantage for the carriers.

Key words: EcNOS; Nitric Oxide; genetic polymorphism; Italy; Ivory Coast 


\section{Introduction}

Nitric oxide (NO) is an endogenous highly reactive molecule that play an important role in the regulation of vascular smooth muscle cell proliferation and migration, in the endothelial permeability, and in the endothelial-leucocyte interaction. Because of these properties, NO has been established as being a regulator of the systemic, cardiac and pulmonary circulations [1], with an important antithrombotic and antimicrobial role $[2,3]$. An impairment of NO production has been showed to be related to many diseases, including coronary artery disease [4], ischemic stroke [5], hypertension [6], renal disease [7], and Alzheimer's disease [8]. At cellular level, an overproduction of NO has been described to be associated to DNA damage, cell cycle arrest, and cellular apoptosis [9], whereas reduction in basal NO release may predispose to hypertension, thrombosis, vasospasm and atherosclerosis [10].

NO is synthesized from the amino acid L-arginine by nitric oxide synthase (NOS) [11]. Three distinct isoforms of NOS, neuronal NOS (nNOS), inducible NOS (iNOS), and endothelial constitutive NOS (ecNOS) have been identified in humans. ecNOS produces the majority of circulating NO [12] and, with nNOS, it is constitutively expressed in both airway and vascular endothelia. The continuously generated NO serve to maintain basal vascular NO production necessary for a good endothelial function and blood flow regulation, particularly coronary flow.

The ecNOS is encoded by a gene located on chromosome 7q35-q36 (13-15) and composed of 26 exons that span more than $21 \mathrm{~kb}$ of the genome [13]. Several polymorphisms were reported in the promotor region, exons, and introns of this gene, and an important one is represented by a 27-base pair core consensus VNTR (variable number of tandem repeats) polymorphism in the intron 4 [14]. The common wild-type 'b-allele' ( $4 \mathrm{~b}$ allele) has five tandem $27-b p$ repeats and has been designated as ecNOS4b, while a rare 'a-allele' (4a allele) has been detected with only four repeats. Tsukada et al. (1998) [15] reported that ecNOS gene polymorphisms correlate with the circulating NO concentrations and individuals with bb and aa genotypes exhibit the highest and the lowest activity, respectively. The four repeats of VNTR, influencing the plasma NO levels and ecNOS protein 
expression $[12,15]$, were reported to be involved in the pathogenesis of several diseases including coronary heart disease [4, 16,17], lung disease [18], hypertension [6, 19], atopic asthma [20], and early-onset colorectal cancer [21].

Published papers about this gene polymorphism refer mostly to case-control studies, and only few population genetic studies were published in order to assess the frequency of this polymorphism in populations worldwide. The aim of this study was to investigate the genetic variability at ecNOS locus in an African population from Ivory Coast and in an European population from Italy, for which no data has been published about ecNOS intron 4 VNTR polymorphism. We also compared our results with those reported from other control populations sampled worldwide, in particular from African and European groups.

\section{Materials and Methods}

\section{Population studied}

The African sampling was performed in Ouangolodougou, a rural village of 20.000 inhabitant located on the Northern Ivory Coast. One hundred twenty-eight unrelated individuals (59 males and 69 females, mean age $31.9 \pm 14,5)$ were analyzed. The Italian sampling was performed in Piedmont, a region of Northern Italy. Two hundred and forty individuals (112 males and 128 females, mean age 58.36 \pm 6.7$)$ were analyzed. All the subjects were healthy volunteers and had received information about the study. The study has been approved by the local ethics committee and has been performed in accordance with the ethical standards laid down in the 1964 Declaration of Helsinki.

\section{PCR Analysis}

Peripheral blood samples (5-10 $\mathrm{ml}$ venipuncture) were collected in heparinized vacutainers and stored at $-20^{\circ} \mathrm{C}$. To extract DNA we used Chelex ${ }^{\circledR}$ solution protocol [22]. To determine the ecNOS genotype, a genomic DNA fragment of intron 4 of the ecNOS gene was amplified by PCR, using 
the following primers: forward primer 5'-AGGCCCTATGGTAGTGCCTTT-3' and the reverse primer 5'-TCTCTTAGTGCTGTGGTCAC-3'. PCR reactions were carried out in a total volume of $25 \mu \mathrm{l}$ containing $10 \mathrm{ng}$ of DNA (template), with a final concentration of $1 \mathrm{X}$ Reaction Buffer, 1.5 $\mathrm{mM}$ of $\mathrm{MgCl} 2,5 \%$ of DMSO, $250 \mu \mathrm{M}$ of dNTPs, $0.5 \mu \mathrm{M}$ of each primer, and $1 \mathrm{U} /$ sample of Taq DNA polymerase (Fischer, U.S.). The reaction profile was: 30 cycles of $94^{\circ} \mathrm{C}$ for $1 \mathrm{~min}, 56^{\circ} \mathrm{C}$ for 1 min., $72^{\circ} \mathrm{C}$ for $1 \mathrm{~min}$, with a final extension at $72^{\circ} \mathrm{C}$ for $10 \mathrm{~min}$. PCR products were separated by electrophoresis on a $4 \%$ Nusive high resolution agarose gel and visualized by ethidium bromide staining. Amplification yielded either a $420 \mathrm{bp}$ (five repeats of the 27-bp sequence) fragment or a $393 \mathrm{bp}$ (four repeats of the 27-bp sequence) fragment or both (heterozygous genotype). A 10\% of the samples were amplified twice for checking the accuracy of the results. Moreover, in order to confirm that the amplified products represent genuine ecNOS intron 4 regions, selected PCR amplified segments, corresponding to $\mathrm{a} / \mathrm{a}$ and $\mathrm{b} / \mathrm{b}$ genotypes, were completely sequenced at both strands.

\section{Statistical analysis}

The allele and genotype frequencies were determined using GENEPOP program. Hardy-Weinberg equilibrium was evaluated by the Chi-square $\left(\chi^{2}\right)$ test using a $95 \%$ confidence interval. Allele frequencies obtained in the studied samples were compared with those reported for other European and African populations, through contingency tables analyzed with a $\chi^{2}$-test.

\section{Results and Discussion}

The frequency distribution of ecNOS 27-bp repeat polymorphism of intron 4 within the study groups was presented in Table 1 . The frequencies of the bb, ab and aa genotypes were $0.422,0.476$, and 0.102 , respectively, for the Ivorian sample, and $0.683,0.300$, and 0.017 , respectively, for the Italian sample. The frequencies of $4 \mathrm{~b}$ and $4 \mathrm{a}$ alleles were 0.660 and 0.340 , respectively, for the Ivorian group, and 0.833 and 0.167 , respectively, for the studied Italian population. 
The genotype frequencies distribution of this polymorphism was in Hardy-Weinberg equilibrium in both populations. Because of existing gender differences in NO production [23, 24], allele and genotype frequencies of the ecNOS polymorphisms were analyzed separately in men and women. No differences were found in ecNOS genotype and allele frequencies distribution between sexes (Table 1).

The ecNOS intron 4 VNTR polymorphism has been analyzed in several human populations (Table 2), mostly in order to ascertain its association with several type of diseases. Results showed a significant $(\mathrm{P}<0.001)$ decreasing gradient of the $4 \mathrm{a}$ allele frequency from Africa to Europe, America and Asia, probably ascribed to a founder effect due to ancient migrations of geographically distinct and isolated groups from Africa to other continents. In addition, being this polymorphism involved in the pathogenesis of several diseases, this different distribution pattern of the allele frequencies could also be the result of a selective pressure exerted on different populations.

Our Ivorian sample showed similar allele frequency values with respect to the other Ivorian sample genotyped for the same polymorphism, but a significantly $(\mathrm{p}<0.001)$ higher frequency of the $4 \mathrm{a}$ allele with respect to North African populations (Tunisia, Algeria and Morocco) and to the AfricanBrazilian sample (Table 2).

This different distribution pattern among Africans could probably be attributed to the different evolutionary histories of the different ethnic groups, in particular of the Northern Africa populations with respect to West and South Africa groups. In Africa, the genetic structure of many otherwise genetically "neutral" systems, such as mitochondrial DNA variation, has already been demonstrated [25]. Therefore, it is not surprising to discover differences between west and north African populations.

Viceversa, the Italian population, did not show any significant level of differentiation with respect to other European populations previously analysed for the same genetic marker, with exception of the Holland and Turkey samples $(\mathrm{p}<0.001)$, confirming the high genetic homogeneity of Italy and Europe in the distribution of this polymorphism. 
According to many global surveys of genetic markers demonstrating that the African populations have consistently greater diversity than other populations [26, 27], our African sample showed an high frequency of heterozygous genotypes, indicating an high level of heterozygosity to the studied locus. It was found that the four repeats of VNTR influence the plasma NO levels. Indeed, the 4a allele of the ecNOS gene was related to low NO metabolite levels, and subjects homozygous for the 4a allele exhibit about $20 \%$ lower levels of NO metabolites than subjects with the $\mathrm{b} / \mathrm{b}$ genotype [15]. Among Ivorians, the 4a allele was found prevalently in a heterozygous status. A possible explanation could be that the heterozygote individuals produce a sufficient level of NO metabolites, although in minor amount with respect to the bb genotypes. As a consequence, the $4 \mathrm{a}$ allele is maintained prevalently in a heterozygous status and does not provoke an effective selective disadvantage for the carriers.

In conclusion, we reported on novel frequency data as regards ecNOS intron 4 VNTR polymorphism in Ivorian and European populations, thereby extending previous observations obtained from other worldwide populations. Considering the implication of this polymorphism in many diseases and the scarcity of data about the prevalence of these diseases principally among African populations, further studies are needed to address the impact of selective constraints on the variability associated to this polymorphism in different populations and ethnic groups.

\section{Acknowledgments}

This work was supported by grants from the "Ministero Italiano dell'Università e della Ricerca Scientifica"

\section{References}

1. Rubino A, Loesch A, Burnstock G (1999) Nitric oxide and endothelin-1 in coronary and pulmonary circulation. Int Rev Cytol 189:59-93. 
2. Draijer R, Astma DE, van der Laarse A (1995) c-GMP and nitric oxide modulate thrombin induced endothelial permeability: regulation via different pathways in human aortic and umbilical vein endothelial cells. Circ Res 76:199-208.

3. Gauthie TW, Scalia R, Murohara T (1995) Nitric oxide protects against leukocyteendothelium interactions in the early stages of hypercholesterolemia. Arterioscler Thromb Vasc Biol 15:1652-1659.

4. Park KW, You KH, Oh S, Chae IH, Kim HS, Oh BH, Lee MM, Park YB (2004) Association of endothelial constitutive nitric oxide synthase gene polymorphism with acute coronary syndrome in Koreans. Heart 90(3):282-285.

5. Munshi A, Rajeshwar K, Kaul S, Chandana E, Shafi G, Anilaa AN, Balakrishnac N, Alladi S, Jyothy A (2010) VNTR polymorphism in intron 4 of the eNOS gene and the risk of ischemic stroke in a South Indian population. Brain Res Bull 82:247-250.

6. Miyamoto Y, Saito Y, Kajiyama N et al., Yoshimura M, Shimasaki Y, Nakayama M, Kamitani S, Harada M, Ishikawa M, Kuwahara K, Ogawa E, Hamanaka I, Takahashi N, Kaneshige T, Teraoka H, Akamizu T, Azuma N, Yoshimasa Y, Yoshimasa T, Itoh H, Masuda I, Yasue H, Nakao K (1998) Endothelial nitric oxide synthase gene is positively associated with essential hypertension. Hypertension 32:3-8.

7. Schmidt RJ, Baylis C (2000) Total nitric oxide production is low in patients with chronic renal disease. Kidney Int 58:1261-1266.

8. Galbusera C, Facheris M, Magni F, Galimberti G, Sala G, Tremolada L, Isella V, Guerini FR, Appollonio I, Galli-Kienle M., Ferrarese C (2004) Increased susceptibility to plasma lipid peroxidation in Alzheimer disease patients. Curr Alzheimer Res 1:103-109.

9. Nguyen T, Brunson D, Crespi CL, Penman BW, Wishnock JS, Tannenbaum SR (1992) DNA damage and mutation in human cells exposed to nitric oxide in vitro. Proc Natl Acad USA 89:3030-3034. 
10. Candipan RC, Wang BY, Buitrago R, Tsao PS, Cooke JP (1996) Regression or progression. Dependency on vascular nitric oxide. Arterioscler Thromb Vasc Biol 16:44-50.

11. Bredt, DS, Snyder SH (1994) Nitric oxide: A physiologic messenger molecule. Annu Rev Biochem 63:175-195.

12. Wang XL, Mahaney MC, Sim AS, Wang J, Wang I, Blangero J, Almasy L, Badenhop RB, Wilcken DE (1997) Genetic contribution of the endothelial constitutive nitric oxide synthase gene to plasma nitric oxide levels. Arterioscler Thromb Vasc Biol 17:3147-3153.

13. Marsden PA, Heng HH, Scherer SW, Stewart RJ, Hall AV, Shi XM, Tsui LC, Schappert KT (1993) Structure and chromosomal localization of the human constitutive endothelial nitric oxide synthase gene. J Biol Chem 268 (23):17478-17488.

14. Wang XL and Wang J (2000) Endothelial nitric oxide synthase gene sequence variations and vascular disease. Mol Genet Metab 70:241-251.

15. Tsukada T, Yokoyama K, Arai T, Takemoto F, Hara S, Yamada A, Kawaguchi Y, Hosoya T, Igari J (1998) Evidence of association of the ecNOS gene polymorphism with plasma NO metabolite levels in humans. Biochem Biophys Res Commun 245:190-193.

16. Wang XL, Sim AS, Wang MX, Murrell GA, Trudinger B, Wang J (2000) Genotype dependent and cigarette specific effects on endothelial nitric oxide synthase gene expression and enzyme activity. FEBS Lett 471:45-50.

17. Ichihara S, Yamada Y, Fujimura T (1998) Association of a polymorphism of the endothelial constitutive nitric oxide synthase gene with myocardial infarction in the Japanese population. Am J Cardiol 81:83-86.

18. Barnes PJ \& Belvisi MG (1993) Nitric oxide and lung disease. Thorax 48:1034-1043.

19. Jemaa R, Ben Ali S, Kallel A, Feki M, Elasmi M, Taieb SH, Sanhaji H, Omar S, Kaabachi N (2009) Association of a 27-bp repeat polymorphism in intron 4 of endothelial constitutive nitric oxide synthase gene with hypertension in a Tunisian population. Clin Biochem 42(9):852-856. 
20. Lee YC, Cheon KT, Lee HB, Kim W, Rhee YK, Kim DS (2000) Gene polymorphisms of endothelian nitric oxide sybthase and angiotensin-converting enzyme in patient with asthma. Allergy 55(10):959-963.

21. Yeh CC, Santella RM, Hsieh LL, Sung FC, Tang R (2009) An intron 4 VNTR polymorphism of the endothelial nitric oxide synthase gene is associated with early-onset colorectal cancer. Int J Cancer 124(7):1565-1571.

22. Walsh PS, Metzger DA, Higuchi R (1991) Chelex 100 as a Medium for simple extraction of DNA for PCR-based typing from forensic material. BioTechniques 10:506-513.

23. Forte P, Kneale BJ, Milne E, Chowienczyk PJ, Johnston A, Benjamin N, Ritter JM (1998) Evidence for a difference in nitric oxide biosynthesis between healthy women and men. Hypertension 32(4):730-734.

24. Tsang KW, Ip SK, Leung R, Tipoe GL, Chan SL, Shum IH, Ip MS, Yan C, Fung PC, ChanYeung M, Lam W (2001) Exhaled nitric oxide: the effects of age, gender and body size. Lung 179(2):83-91.

25. Salas A, Richards M, De la Fe T, Lareu MV, Sobrino B, Sánchez-Diz P, Macaulay V and Carracedo A (2002) The making of the African mtDNA landscape. Am J Hum Genet 71:1082-1111.

26. Goldstein DB, Lineares AR, Cavalli-Sforza LL, Feldman MW (1995). Genetic absolute dating based on microsatellites and the origin of modern humans. Proc Natl Acad Sci 92:6723-6727.

27. Garrigan D and Hammer MF. (2006) Reconstructing human origins in the genomic era. Nature Reviews/Genetics 7:669-680.

28. Jemaa R, Kallel A, Ben Ali S, Omar S, Chabrak S, Elasmi M, Haj Taieb S, Sanhaji H, Feki M, Mechmeche R, Kaabachi N (2007) Association of a 27-bp repeat polymorphism in intron 
4 of endothelial constitutive nitric oxide synthase gene with myocardial infarction in Tunisian patients. Clin Chem Lab Med 45(11):1476-1480.

29. Djidjih R, Ghaffor M, Brun M, Gharnaout M, Salah SS, Boukouaci W, Djidjik H, Benyouness A, Koumaravelou K, Krishnamoorthy R, Abbadi MC, Charron D (2007) Constitutive nitric oxide synthase gene polymorphisms and house dust mite respiratory allergy in an Algerian patient group. Tissue Antigens 71:160-164.

30. Via M, González-Pérez E, Esteban E, López-Alomar A, Vacca L, Vona G, Dugoujon JM, Harich N, Moral P (2003) Molecular variation in endothelial nitric oxide synthase gene (eNOS) in western Mediterranean populations. Coll Anthropol 27:117-124

31. Rios DLS, D’Onofrio LO, Souza JK, QUeiroz AM (2007) Smoking-dependent and haplotype-spcific effects of endothelial nitric oxide synthase gene polymorphisms on angiographically assessed coronary artery disease in Caucasian- and African-Brazilians. Atherosclerosis 193:135-141.

32. Li R, Lyn D, Lapu-Bula R, Oduwole A, Igho-Pemu P, Lankford B, Morgan J, Nkemdechi S, Liu G, Pack C, Silvestrov N, von Deutsch DA, Song Q, Abukhalaf IK, Ofili E (2004). Relation of endothelial nitric oxide synthase gene to plasma nitric oxide level, endothelial function, and blood pressure in African Americans. Am J Hypertens 17(7):560-567.

33. Mearin F, García-González MA, Strunk M, Zárate N, Malagelada JR, Lanas A (2006) Association between achalasia and nitric oxide synthase gene polymorphisms. Am J Gastroenterol 101(9):1979-1984.

34. Agema WRP, De Maat MPM, Zwinderman AH, Kastelein JJP, Rabelink TJ, Van Boven AJ, Feskens EJM, Boer JMA, Van Der Walle EE, Jukema JW (2004) An integrated evaluation of endothelial constitutive nitric oxide synthase polymorphisms and coronary artery disease in men. Clin Sci 107:255-261. 
35. Akar N, Akar E, Cin S, Deda G, Avcu F, Yalçin A (1999) Endothelial nitric oxide synthase intron 4, 27 bp repeat polymorphism in Turkish patients with deep vein thrombosis and cerebrovascular accidents. Thromb Res 94(1):63-64.

36. Olcay A, Ekmekci CG, Ozbek U, Sezer M, Barcin C, Arslan E, Boztosun B, Nisanci Y (2006) Negative association of endothelial nitric oxide gene polymorphism with hypertension in Turkish patients: effect of ecNOS polymorphism on left ventricular hypertrophy. Cardiovasc Ultrasound 4:33.

37. Cine N, Hatemi AC, Erginel-Unaltuna N. (2002) Association of a polymorphism of the ecNOS gene with myocardial infarction in a subgroup of Turkish MI patients. Clin Genet 61(1):66-70.

38. Buraczynska M, Ksiazek P, Zaluska W, Nowicka T, Ksiazek A (2004) Endothelial nitric oxide synthase gene intron 4 polymorphism in patients with end-stage renal disease. Nephrol Dial Transplant 19:2302-2306.

39. Gardemann A, Lohre J, Cayci S, Katz N, Tillmanns H, Haberbosch W (2002) The T allele of the missense Glu(298)Asp endothelial nitric oxide synthase gene polymorphism is associated with coronary heart disease in younger individuals with high atherosclerotic risk profile. Atherosclerosis 160(1):167-175.

40. Sigusch HH, Surber R, Lehmann MH, Surber S, Weber J, Henke A, Reinhardt D, Hoffman A, Figulla HR (2000) Lack of association between 27-bp repeat polymorphism in intron 4 of the endothelial nitric oxide synthase gene and the risk of coronary artery disease. Scand $\mathrm{J}$ Clin Lab Invest 60:229-235.

41. Hefler LA, Ludwig E, Lampe D, Zeillinger R, Leodolter S, Gitsch G, Koelbl H, Tempfer CB (2002) Polymorphisms of the endothelial nitric oxide synthase gene in ovarian cancer. Gynecol Oncol 86(2):134-137.

42. Holla LI, Jurajda M, Pohunek P, Znojil V (2008) Haplotype analysis of the endothelial nitric oxide synthase gene in asthma. Hum Immunol 69(4-5):306-313. 
43. Pulkkinen A, Viitanen L, Kareinen A, Lehto S, Vauhkonen I, Laakso M (2000) Intron 4 polymorphism of the endothelial nitric oxide synthase gene is associated with elevated blood pressure in type 2 diabetic patients with coronary heart disease. J Mol Med 78(7):372-379.

44. Fowkes FG, Lee AJ, Hau CM, Cooke A, Connor JM, Lowe GD (2000) Methylene tetrahydrofolate reductase (MTHFR) and nitric oxide synthase (ecNOS) genes and risks of peripheral arterial disease and coronary heart disease: Edinburgh Artery Study. Atherosclerosis 150(1):179-185.

45. Lamnissou K, Zirogiannis P, Trygonis S, Demetriou K, Pierides A, Koptides M, Deltas CC (2004) Evidence for association of endothelial cell nitric oxide synthase gene polymorphism with earlier progression to end-stage renal disease in a cohort of Hellens from Greece and Cyprus. Genet Test 8(3):319-324.

46. Mamoulakis D, Bitsori M, Galanakis E, Vazgiourakis V, Panierakis C, Goulielmos GN (2009) Intron 4 polymorphism of the endothelial nitric oxide synthase eNOS gene and early microangiopathy in type 1 diabetes. Int J Immunogenet 36:153-157.

47. Luizon MR, Izidoro-Toledo TC, Simoes AL, Tanus-Santos JE (2009). Endothelian Nitric Oxide Synthase Polymorphisms and Haplotypes in Amerindians. DNA Cell Biol 28(7):329334.

48. Serrano NC, Diaz LA, Casas JP, Hingorani AD, de Lucca DM, Páez MC (2010). Frequency of eNOS polymorphisms in the Colombian general population. BMC Genetics 11:54-61.

49. Cheon KT, Choi KH, Lee HB, Park SK, Rhee YK, Lee YC (2000) Gene polymorphisms of endothelial nitric oxide synthase and angiotensin-converting enzyme in patients with lung cancer. Lung 178(6):351-360.

50. Koo KH, Lee JS, Lee YJ, Kim KJ, Yoo JJ, Kim HJ (2006) Endothelial nitric oxide synthase gene polymorphisms in patients with nontraumatic femoral head osteonecrosis. J Orthop Res 24(8):1722-1728. 
51. Deng F, Hu Q, Tang B, He F, Guo S, Chen J, Li F, Wu X, Zhang J, Zhang H, Zhao J, Zhong H, He L, Li J, Zhang L, Wang S (2007) Endothelial nitric oxide synthase gene intron 4, 27 bp repeat polymorphism and essential hypertension in the Kazakh Chinese population. Acta Biochim Biophys Sin 39(5):311-316.

52. Lin NT, Lee MJ, Lee RP, Hong AI, Chen HI (2008) Analysis of endothelial nitric oxide synthase gene polymorphisms with cardiovascular diseases in eastern Taiwan. Chin $\mathrm{J}$ Physiol 51(1):42-47.

53. Tripathi G, Sharma RK, Baburaj VP, Sankhwar SN, Jafar T, Agrawal S (2008) Genetic risk factors for renal failure among north Indian ESRD patients. Clin Biochem 41(7-8):525-531.

54. Angeline T, Isabel W, Tsongalis GJ (2010). Endothelial nitric oxide gene polymorphisms, nitric oxide production and coronary artery disease risk in a South Indian population. Exp Mol Pathol 89:205-208.

55. Gururajan P, Gurumurthy P, Victor D, Srinivasa Nagaswara Rao G, Sai Babu R, Sarasa Bharati A (2011). Plasma Total Nitric Oxide and Endotelian Constitutive Nitric Oxide Synthase (ecNOS) Gene Polymorphism: A study in a South Indian Population. Biochem Genet 49:96-103.

56. Khajoee V, Kariyazono H, Ohno T, Ihara K, Mizuno Y, Kusuhara K, Hara T. (2003) Inducible and endothelial constitutive nitric oxide synthase gene polymorphisms in Kawasaki disease. Pediatr Int 45(2):130-134.

57. Nagase S, Suzuki H, Wang Y, Kikuchi S, Hirayama A, Ueda A, Takada K, Oteki T, Obara M, Aoyagi K, Koyama A (2003) Association of ecNOS gene polymorphisms with end stage renal diseases. Mol Cell Biochem 244(1-2):113-118.

58. Neugebauer S, Baba T, Watanabe T (2000) Association of the nitric oxide synthase gene polymorphism with an increased risk for progression to diabetic nephropathy in type 2 diabetes. Diabetes 49(3):500-503. 
59. Asakimori Y, Yorioka N, Yamamoto I, Okumoto S, Doi S, Hirai T, Taniguchi Y (2001) Endothelial nitric oxide synthase intron 4 polymorphism influences the progression of renal disease. Nephron 89(2):219-223. 
Table 1 - Allele and Genotype Frequencies of intron 4 VNTR ecNOS gene polymorphism in the studied populations

\begin{tabular}{|c|c|ccc|cc|}
\hline Population & $\mathrm{N}$ & \multicolumn{3}{|c|}{ Genotype (frequency) } & \multicolumn{2}{c|}{ Allele (frequency) } \\
& & $\mathrm{bb}$ & $\mathrm{ba}$ & $\mathrm{aa}$ & $\mathrm{b}$ & $\mathrm{a}$ \\
\hline Ivory Coast & 128 & $54(0.422)$ & $61(0.476)$ & $13(0.102)$ & $169(0.660)$ & $87(0.340)$ \\
\hline Male & 58 & $28(0.483)$ & $22(0.379)$ & $8(0.138)$ & $78(0.672)$ & $38(0.328)$ \\
\hline Female & 70 & $26(0.372)$ & $39(0.557)$ & $5(0.071)$ & $91(0.650)$ & $49(0.350)$ \\
\hline & & & & & & \\
\hline Italy & 240 & $164(0.683)$ & $72(0.300)$ & $4(0.017)$ & $400(0.833)$ & $80(0.167)$ \\
\hline Male & 112 & $78(0.696)$ & $34(0.304)$ & $0(0.000)$ & $190(0.848)$ & $34(0.152)$ \\
\hline Female & 128 & $86(0.672)$ & $38(0.297)$ & $4(0.031)$ & $210(0.820)$ & $46(0.180)$ \\
\hline
\end{tabular}


Table 2 - Allele and Genotype Frequencies of intron 4 VNTR ecNOS gene polymorphism in the studied and other populations worldwide distributed

\begin{tabular}{|c|c|c|c|c|}
\hline \multirow[t]{2}{*}{ Population } & \multirow[t]{2}{*}{$\mathrm{N}$} & \multicolumn{2}{|c|}{ Allele (frequency) } & \multirow[t]{2}{*}{ References } \\
\hline & & $\mathrm{b}$ & $\mathrm{a}$ & \\
\hline \multicolumn{5}{|l|}{ Africa } \\
\hline Ivory Coast & 128 & $169(0.660)$ & $87(0.340)^{*}$ & Present Study \\
\hline Tunisia & 250 & $431(0.862)$ & $69(0.138) *$ & [28] \\
\hline Algeria & 122 & $202(0.828)$ & $42(0.172)^{*}$ & [29] \\
\hline Morocco (Berber) & 117 & $190(0.812)$ & $44(0.188)^{*}$ & [30] \\
\hline Ivory Coast & 109 & $138(0.633)$ & $80(0.367)$ & [30] \\
\hline African-Brazilians & 121 & $194(0.802)$ & $48(0.198)^{*}$ & [31] \\
\hline African-Americans & 58 & $81(0.698)$ & $35(0.302)$ & [32] \\
\hline Pooled Africa & 905 & $1405(0.776)$ & $405(0.224)^{a, b, c}$ & \\
\hline \multicolumn{5}{|l|}{ Europe } \\
\hline Italy & 240 & $400(0.833)$ & $80(0.167)^{\&}$ & Present Study \\
\hline Italy (Sardinia) & 189 & $336(0.889)$ & $42(0.111)$ & {$[30]$} \\
\hline Spain & 499 & $859(0.861)$ & $139(0.139)$ & {$[30,33]$} \\
\hline Holland & 466 & $839(0.900)$ & $93(0.100)^{\&}$ & [34] \\
\hline Turkey & 488 & $873(0.894)$ & $103(0.106)^{\&}$ & {$[35,36,47]$} \\
\hline Polish & 321 & $553(0.861)$ & $89(0.139)$ & [38] \\
\hline Germany & 941 & $1572(0.835)$ & $310(0.165)$ & {$[39,40]$} \\
\hline Austria & 133 & $228(0.857)$ & $38(0.143)$ & [41] \\
\hline Czech Republic & 316 & $517(0.818)$ & $115(0.182)$ & [42] \\
\hline Finland & 110 & $184(0.836)$ & $36(0.164)$ & [43] \\
\hline Scotland & 300 & $526(0.877)$ & $74(0.123)$ & [44] \\
\hline Greece & 295 & $492(0.834)$ & $98(0.166)$ & [45] \\
\hline Greece, Crete & 160 & $279(0.872)$ & $41(0.128)$ & [46] \\
\hline Pooled Europe & 4458 & $7658(0.859)$ & $1258(0.141)^{a, d}$ & \\
\hline \multicolumn{5}{|l|}{ America } \\
\hline Amerindians & 170 & $326(0.959)$ & $14(0.041)$ & [47] \\
\hline Colombia & 859 & $1474(0.858)$ & $244(0.142)$ & [48] \\
\hline Pooled America & 1029 & $1800(0.875)$ & $258(0.125)^{b}$ & \\
\hline \multicolumn{5}{|l|}{ Asia } \\
\hline South Korea & 224 & $412(0.920)$ & $36(0.080)$ & {$[49,50]$} \\
\hline China & 216 & $392(0.907)$ & $40(0.093)$ & {$[51,52]$} \\
\hline India & 769 & $1274(0.828)$ & $264(0.172)$ & {$[53,54,55]$} \\
\hline Japan & 1329 & $2409(0.906)$ & $249(0.094)$ & {$[17,56,57,58,59]$} \\
\hline Pooled Asia & 2538 & $4487(0.884)$ & $589(0.116)^{c, d}$ & \\
\hline
\end{tabular}

$*=$ significantly different $(\mathrm{P}<0.001)$ with respect to our studied Ivorian sample

$\&=$ significantly different $(\mathrm{P}<0.001)$ with respect to our studied Italian sample $a, b, c, d=\mathrm{P}<0.001$ 